\title{
Analisis Ekonomi Dalam Pembentukan Hukum
}

\author{
Siti Azizah
}

Dosen Bagian Hukum Internasional Fakultas Hukum Universitas Lampung

\begin{abstract}
Indeed the legal establishment aspired by the 1945 Constitution is economic development and legal development that includes political and cultural development is also derived from the word "achieve sosial justice for all Indonesian peoples" is a form of justice in many respects. The complexity of economic problems, economic integration and technological nations in the trading process has a lot to make the laws contained in economic interest that so many laws actually lead to wrong interpretation by the general public so that the need for strict enforcement of government officials.
\end{abstract}

Keyword: Analisis Ekonomi, dan pembentukan hukum.

\section{Pendahuluan}

Salah satu tujuan dibentuknya hukum adalah kepentin untuk menjamin berbagai kepentingan, seperti kepentingan ekonomi, perlindungan terhadap kepentingan pribadi, kehormatan perorangan, politik, agama dan lain sebagainya. Dari kepentingan-kepentingan diatas tersebut kepentingan ekonomi merupakan salah satu indikator yang paling kuat yang menpengaruhi penciptaan hukum. ${ }^{1}$ Sebagaimana diketahui pembentukan hukum sangat dipengaruhi oleh berbagai faktor diluar hukum seperti faktor sosial, politik, ekonomi, budaya, dan lain-lain. Salah satu Sarjana yang mengakui adanya faktor-faktor diluar hukum yang mempengaruhi pembentukan hukum adalah Max Weber. $^{2}$

\footnotetext{
${ }^{1}$ Hari chand, Modern Jurisprudence (Kuala Lumpur, International Law Book Service ,1994,) Hlm. 177.

${ }^{2}$ Max Weber adalah seorang ahli hukum kelahiran Jerman dan sempat menempuh pendidikan di Sekolah Jurisprudensi Sejarah
}

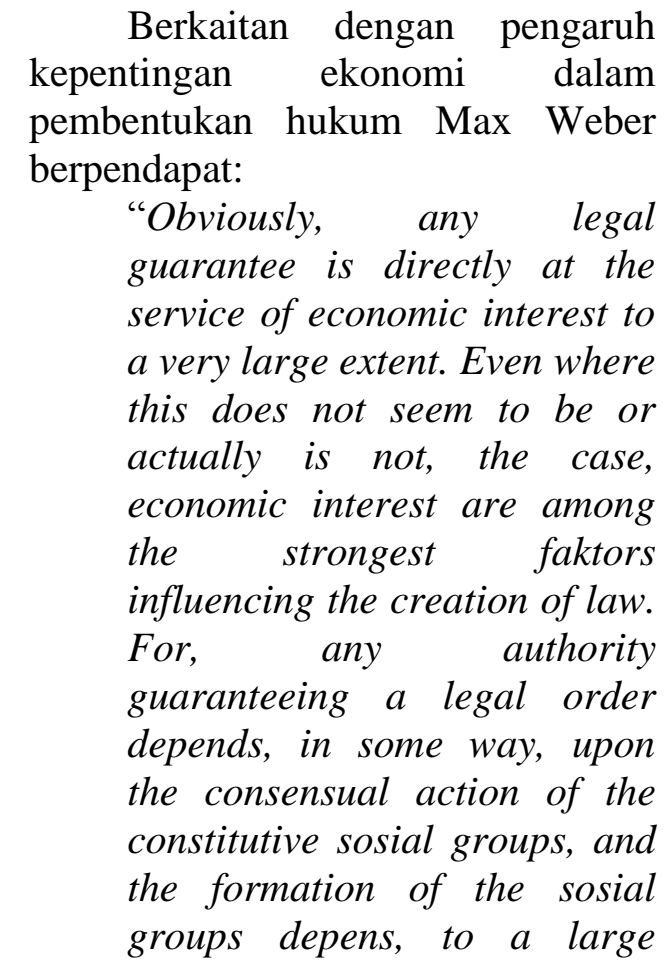

di Jerman dan banyak mempelajari hukum Romawi, Hindu, Inggris dan Hukum Eropa. Pemikirannya banyak dipengaruhi oleh pandangan Karl Marx bahwa sruktur ekonomi menentukan politik, seni, hukum, filsafat, dan bidang lainnya. Namun Weber menentang pendapat Karl Marx tentang determinasi ekonomi.Bukunya yang terkenal adalah "Ekonomi and Society". 
extent upon constellation of material interest". 3

Secara bebas diterjemahkan “...terlihat jelas bahwa jaminan hukum ditujukan langsung pada pelayanan kepentingan ekonomi sampai pada batas-batas yang luas. Meskipun pada kenyataannya keadaan yang ada tidak persis seperti itu, namun kepentingan-kepentingan ekonomi adalah salah satu di antara faktor-faktor yang terkuat yang mempengaruhi penciptaan hukum. ${ }^{4}$

Bagi pemerintah yang menjamin perintah hukum, bergantung pada beberapa cara, yaitu pada tindakan konsensual kelompokkelompok sosial konstitutif, dan formasi kelompok-kelompok sosial tersebut bergantung pada sejumlah konstilasi kepentingan-kepentingan materiil sampai pada batas yang luas.

Sebagai pengikut aliran sosiologi, pendapat Weber tidak dapat dilepaskan dari pandanganpandangan sosiolog bahwa hukum dilihat sebagai suatu gejala yang ada di dalam masyarakat yang keberadaannya dipengaruhi oleh gejala-gejala lain yang terdapat dalam masyarakat bersangkutan. Meski tidak sekaku pendapat Karl Marx yang memandang pembentukan hukum ditentukan oleh kepentingan ekonomi atau hukum merupakan produk langsung kekuatan ekonomi, namun Weber menganggap bahwa kepentingan ekonomi merupakan faktor dominan dalam pembentukan hukum dan di lain pihak hukum dapat mempengaruhi system ekonomin yang ada dalam masyarakat.

\footnotetext{
${ }^{3}$ Hari Chand, op.cit.

4 Menurut Weber, aktivitas dasar yang terdapat dalam bidang hukum ada dua yaitu penciptaan hukum dan penemuan hukum.
}

Hukum dipandang sebagai kekuatan otonom dalam perkembangan sosial, sehingga hukum mempengaruhi perkembang-an ekonomi sementara hukum dipengaruhi oleh kekuatan-kekuatan ekonomi, namun Weber tetap menyadari bahwa keberadaan hukum selalu saja dimaksudkan untuk melayani kepentingan-kepentingan ekonomi. $^{5}$

Keberadaan ekonomi yang sangat pesat menciptakan kelompokkelompok atau kelas sosial tertentu yang mempunyai kekuatan dalam masyarakat.

Kepentingan-kepentingan

kelompok-kelompok sosial yang memegang kendali pasar ini pada kenyataannya sangat berpengaruh dalam menentukan kebijakan Negara atau pemerintah khususnya yang berkaitan dengan jaminan keamanan usaha-usaha mereka baik di tingkat nasional maupun internasional. ${ }^{6}$

Lebih lanjut system di dunia modern yang makin kompleks mengharuskan tersedianya jaminan ketertiban hukum oleh Negara, sehingga kelompok-kelompok yang mempunyai peran dalam bidang ekonomi menuntut adanya system hukum yang menjamin predictability (dapat diramalkan), calculability (dapat diperhitungkan), dan kepastian-kepastian terhadap berlangsungnya transaksi-transaksi ekonomi. ${ }^{7} \mathrm{Hal}$ tersebut sangat relevan karena suatu transaksi ekonomi tidak lepas dari konsekuensi-konsekuensi untung dan rugi sehingga mereka memerlukan

\footnotetext{
${ }^{5}$ Hari Chand, op. cit. hlm. 178.

${ }^{6}$ T. Mulya lubis dan Richard M. Buxbaum, ed. "Peranan Hukum dalam Perekonomian Di Negara Berkembang" (Jakarta :yayasan LBHI), tanpa tahun. hlm. 21-22.

${ }^{7}$ Hari Chand, op.cit. hlm. 177.
} 
prediksi dan perhitungan yang akurat serta jaminan kepastian hukum terhadap kensekwensi-konsekwensi yang harus mereka tanggung.

Menurut Weber transaksitransaksi ekonomi (pasar ekonomi) hanya bisa berkembang jika konsekuensi-konsekuensi hukum dari transaksi ekonomi dapat diramalkan secara pasti.

Lebih lanjut Weber mengatakan bahwa kepentingankepentingan kelas yang ada di masyarakat semakin beragam dan mempunyai perbedaan yang tajam daripada masa sebelumnya. Laju komunikasi bisnis modern yang makin cepat membutuhkan system hukum yang berfungsi secara tepat dan dapat diramalkan, ${ }^{8}$ seperti misalnya sistem hukum yang dijamin dengan kekuatan paksaan yang terkuat. Pada akhirnya kehidupan ekonomi modern tersebut dengan karakter dasar yang dimilikinya telah meningkirkan kelompok-kelompok kepentingan lainnya yang sebelumnya mengemban dan mendapat jaminan hukum. Hal tersebut merupakan proses pengembangan pasar dimana kekuatan universal dari market consociation mensyaratkan berfungsinya system hukum yang dapat diperhitungkan dengan aturanaturan rasional pada satu pihak. Sedangkan pada pihak yang lain pengembangan secara tetap dari market consociation telah menunjang monopolisasi dan pengaturan segala kekuatan memaksa yang sah yang dibuat oleh suatu institusi pemaksa universal melalui disintegrasi semua

\footnotetext{
${ }^{8}$ Dalam prakteknya, investor yang akan menanamkan modalnya pada suatu Negara akan menuntut persyaratan utama berupa jaminan hukum dan keamanan bagi kelangsungan bisnisnya
}

status tertentu dan struktur-struktur pemaksa lainnya, yang selama ini kebanyakan bergantung pada monopoli-monopoli ekonomi. ${ }^{9}$

Perkembangan kekuatan ekonomi sangat erat kaitannya dengan hukum kontrak. Dalam hukum kontrak terdapat keterkaitan antara ekspansi pasar dan kebebasan kontraktual, dimana kebebasan kontraktual yang merupakan kebebasan para pihak dalam menentukan isi kontrak yang mereka sepakati pada kenyataannya bukanlah kebebasan yang tanpa batas. ${ }^{10}$ Latar belakang munculnya pembatasan-pembatasan tersebut adalah karena adanya kepentingankepentingan dari Negara serta kepentingan para pihak itu sendiri yang berorientasi pada pasar. Dengan kata lain jika Negara menganggap ada kepentingan-kepentingan tertentu yang harus dilindungi, maka Negara dapat memberlakukan keinginannya meskipun hal tersebut berada di luar kesepakatan para pihak. Pada sisi lain para pihak sendiri dapat memberlakukan ketentuan-ketentuan yang tujuannya semata-mata kepentingan pasar demi pencapaian keuntungan yang diharapkan. ${ }^{11}$ Selanjutnya pihak yang

\footnotetext{
${ }^{9}$ Ibid.

${ }^{10}$ Pada prinsipnya dalam hukum kontrak berlaku ketentuan bahwa para pihak bebas menentukan materi atau isi kontrak sepanjang tidak bertentangan dengan asasasas umum yang berlaku dalam hukum kontrak, namun dalam perkembangannya kebebasan berkontrak tersebut sangat dipengaruhi berbagai faktor termasuk kepentingan Negara atau pemerintah.

${ }^{11}$ Dalam hukum perdata dikenal "Standar Kontrak" dimana salah satu pihak telah mencantumkan syarat-syarat tertentu yang harus disetujui oleh pihak yang lain. Standar kontrak ini lazim berlaku pada perjanjian
} 
$\begin{array}{lrr}\text { memiliki posisi lebih } & \text { kuat } \\ \text { mempunyai } & \text { kesempatan } & \text { untuk } \\ \text { memaksakan } & \text { syrat-syarat yang } \\ \text { dikehendakinya kepada pihak yang } & \text { kada } \\ \text { lebih lemah } & \text { melalui aturan-aturan } \\ \text { hukum. } & \end{array}$

Sehubungan dengan

transaksi-transaksi ekonomi yang terus berkembang pesat maka dibutuhkan aturan hukum yang mampu diterapkan secara efektif dalam masyarakat dan sedemikian rupa mampu diterapkan secara efektif dalam masyarakat dan sedemikian rupa mampu melindungi kepentingan ekonomi. Pada sisi yang lain sangatlah beresiko jika Negara tidak mampu memberi kepastian dari perlindungan hukum pada kepentingan ekonomi yang ada karena pada dasarnya sasaran atau tujuan kegiatan ekonomi adalah peningkatan kesejahteraan masyarakat. ${ }^{13}$ Oleh karenanya jika kegiatan ekonomi terganggu maka kesejahteraan masyarakat dapat terhambat bahkan hukum itu sendiri akan menerima dampaknya.

Dukungan kepada kepentingan ekonomi melalui penerapan aturanaturan hukum dapat dilakukan

dengan kedudukan salah satu pihak lebih dominan dari pada pihak yang lain.

${ }^{12}$ Hary C hand, op. cit, h. 181

13 Pentingnya hukum dalam menjamin jalannya perekonomian dapat dilihat dalam perencanaan pembangunan ekonomi. Suatu perencanaan ekonomi misalnya, membutuhkan kepastian mengenai kekuatan pemilikan atas tanah, gedung dan kekayaan lainnya, agar kesemuanya dapat diperhitungkan secara tepat dan akurat khususnya berkaitan dengan cost. Tanpa bantuan hukum semua itu sulit diperhitungkan karena akan tergantung pada pihak-pihak ( tidak ada kepastian ). Jaminan kepastian hukum diperlukan pada setiap unsur kegiatan perencanaan ekonomi seperti kontrak, pajak, dan sebagainya. (Sudjono:1993:13). melalui pemaksaan pemenuhan syarat-syarat tertentu yang dikehendaki kalangan yang mendukung kepentingan ekonomi. Pencantuman syarat-syarat tersebut menurut Max Weber memang dimungkinkan. Melalui "konsep dominasi", ${ }^{14}$ Weber menjelaskan adanya kemungkinan bagi seseorang atau pihak-pihak untuk memberlakukan kehendaknya pada orang lain.

Konsep dominasi ini muncul dalam berbagai bentuk, seperti kedudukan monopoli. ${ }^{15}$ Dicontohkan oleh Weber tentang suatu bank yang menetapkan syarat-syarat khusus dalam memberikan pinjaman bagi pengusaha yang mempunyai kekuatan dapat mengendalikan pasar, atau seorang professor yang dapat mengatur perilaku murid-muridnya melalui pemaksaan pemenuhan aturan yang dibuatnya. ${ }^{16}$

Istilah dominasi digunakan sebagai istilah yang identik dengan kekuasaan otoriter yang bersifat memaksa. Weber tidak menyangkal keberadaan kekuatan nyata dan dominasi, tetapi ia lebih menekankan pada bentuk-bentuk legitimasi kekuatan. Dominasi hukum dianggap sebagai dominasi yang terlegitimasi

\footnotetext{
${ }^{14}$ Ibid

15 Dalam hukum kontrak, pemberlakuan syarat-syarat tertentu atau khusus oleh satu pihak kepada pihak lain dikenal dengan istilah "standart contract", dimana dalam praktek kontrak telah tertuang dalam formulir tertentu dan tidak ada pilihan lain bagi pihak yang lemah selain menerima syarat-syarat kontrak yang telah ditentukan (tidak ada kesempatan untuk bernegosiasi ).

16 Contoh tersebut merupakan bentuk standar kontrak, dimana pihak yang berposisi lemah didorong oleh kepentingan untuk memperoleh sesuatu mau tidak mau harus mentaati ketentuan yang dibuat pihak yang berposisi kuat.
} 
dalam masyarakat occidental. Dalam hal ini masyarakat dapat termotivasi untuk mentaati perintah atas dasar:

$>$ Keyakinan mereka atas kebenaran perintah tersebut atau dengan sense of duty mereka,

$>$ Atau dengan ketakutan atau dengan kebiasaan,

$>$ Atau dengan keinginan untuk mendapatkan beberapa manfaat bagi dirinya sendiri.

Hal penting dari pemikiran Max Weber adalah kategorisasi pemikiran hukum yang terbagi dalam dua kategori, yaitu:

1. Kategori irasional, yang dapat berbentuk irasionalitas formal dan irasionalitas substansial; dan

2. Kategori rasionalitas, yang dapat berbentuk rasionalitas formal dan rasionalitas substansial.

Irrasionalitas formal adalah cara yang digunakan dalam pembuatan hukum dan penemuan hukum yang tidak dapat dikontrol dengan intelektualitas. Sedangkan irasionalitas substantive berarti bahwa keputusan dari pembentukan hukum atau penemuan hukum lebih dipengaruhi faktor-faktor konkret tertentu yang telah dievaluasi atas dasar etika, emosional, atau politik dari norma-norma umum.

Rasionalitas formal adalah bahwa dalam aspek-aspek subtansial hanya karakteristik-karakteristik dari fakta-fakta kasus yang umum dan yang jelas saja yang dipertimbangkan, sedangkan rasionalitas subtantif berarti bahwa keputusan tentang persoalanpersoalan hukum dipengaruhi oleh norma-norma yang berbeda dari norma yang diperoleh melalui generalisasi logis, seperti etika imperatif, kepraktisan atau aturanaturan lainnya termasuk pernyataan politik. Disadari oleh Weber bahwa dalam mencapai rasionalitas oleh hukum, hukum rasionalitas formal dapat mengalami kekurangadilan, oleh karenanya dimungkingkan timbul ketegangan-ketegangan dalam hukum rasional formal.

formal dalam sistem hukum
mendorong mendorong sistem hukum untuk bekerja layaknya mesin rasionalitas secara teknis. Pengenalan tersebut menjamin tiap individu dan kelompok suatu kebebasan yang maksimal secara relaktif. Oleh karenanya keadilan formal bertentangan dengan kekuatan-kekuatan otoriter, teokratis,dan patriarkis karena keadilan tersebut mengurangi ketergantungan individu terhadap kewibawaan dan kekuasaan yang berwenang. ${ }^{17}$ Kelompok-kelompok inilah yang dalam masyarakat membutuhkan stabilitas dan kepastian prosedur hukum, khususnya organisasi-organisasi ekonomi dan politik menghendaki memiliki sistem hukum rasional secara formal. Permasalahannya adalah bagaimanakah hubungan ekonomi dengan perubahan sosial dalam konteks perundang-undangan di Indonesia?

\section{Pembahasan}

Keterkaitan hukum dengan perubahan sosial sangatlah erat ,karena hukum selalu mengikuti perubahan sosial yang ada dimasyarakat hukum. Dengan demikian pembentukan hukum selalu dipengaruhi oleh perubahan

\footnotetext{
${ }^{17}$ Konsep keadilan yang didasarkan pada pengembangan rasionalitas dari eber banyak di kritik oleh sarjana lain, karena dapat menjadi sumber ketegangan. Oleh karenanya perlu dibenahi tidak hanya dari aspek rasionalitas formal tapi juga dari sisi etika.
} 
sosial.Berkaitan dengan hal tersebut Von Savigny 18 dan Bentham mempunyai pandangan yang saling bertentangan, ${ }^{19}$ menurut Savigny hukum itu tidak dibuat melainkan ditentukan oleh kebiasaan yang berlaku dalam masyarakat atau melalui putusan hakim.Jika kebiasaan tersebut telah menjadi sempurna dan diterima oleh masyarakat,maka barulah badan hukum pembentuk undang-undang menetapkan kebijaksanaan atau menetapkan kebiasaan tersebut sebagai hukum.

Sedangkan Bentham ${ }^{20}$ seorang penganut paham pentingnya pembaharuan hukum yang disusun secara rasional, berpendapat bahwa keberadaan hukum adalah dibuat oleh aparatur Negara yaitu pemerintahan, lembaga legislatif, dan oleh hakim dalam proses peradilan untuk mengatasi perubahan sosial yang terjadi dimasyarakat. Pendapat Savigny dan Bentham yang saling bertentangan kemudian dipadukan melalui metode pendekatan yang dilakukan oleh Eugen Erhlich. Menurut Erhlich hukum tumbuh dan berkembang dalam masyarakat serta dibuat oleh aparat yang berwenang

\footnotetext{
18 Von Savigny adalah seorang professor bidang buku berasal dari Universitas Berlin (1779-1861) yang menentang pemberlakuan undang-undang Napoleon di Jerman dan mendukung hukum yang hidup dari dan didukung oleh masyarakat.

${ }^{19}$ Sudjono Dirdjosisworo, Sosiologi Hukum Studi Tentang Perubahan Hukum dan Sosial, hh. 1-3

${ }^{20}$ Jeremy Bentham (1748-1832 ) dikenal sebagai pahlawan kodifikasi hukum dan pembentukan hukum inggris yang menganut filsafat utilitarianisme, bukunya "The Limits Jurisprudence Defined" telah mengantarnya sebagai bapak Jurisprudensi Inggris pada tahun 1945.
}

dan lahir dari dalam proses peradilan. $^{21}$

Selanjutnya perubahan sosial itu sendiri terjadi karena adanya pengaruh-pengaruh kepentingan dalam masyarakat. Hal ini sesuai dengan observasi dari Alan Hunt dalam bukunya "The sociological Movement in Law" mengenai perubahan sosial yang terjadi di Amerika,bahwa:

"in period of rapid sosial and economic change the America legal system,common Law based on and dominated by legal traditionalism, was beset by widw Ringing criticism. It was pressed by contending forces in sosial conflict in contradictory directions.It had neither time nor opportunity for a leisurely adjustment to the changed circumstance. The pressure from tehe rapidly emerging labour movement brought pressure on the legislator for intervention through sosial legislation." 22

Berdasarkan observasi tersebut dapat dilihat bahwa perubahan sosial dan ekonomi yang berlangsung secara cepat telah mampu mengubah sistem hukum di Amerika, dimana hukum ditekan oleh berbagai kepentingan dan konflik-konflik sosial yang saling bertentangan pada kenyataannya hukum tidak memiliki kesempatan dan waktu untuk menyesuaikan dengan perubahanperubahan tersebut. Tekanan dari pihak tertentu yang tergolong kuat seperti para buruh memaksa pembuat undang-undang melakukan intervensi melalui legislasi sosial. ${ }^{23}$

\footnotetext{
${ }^{21}$ Sudjuno dirdjosisworo, op. cit, hh. 4-7.

${ }^{22}$ Hari C Hand, op.cit., h. 195

23 Buruh merupakan kelompok yang memiliki kekuatan dalam masyarakat, karena keberadaan mereka sangat menentukan keberlangsungan proses
} 
Hal tersebut menunjukan bahwa kepentingan dan tekanan dari suatu pihak yang mempunyai kekuatan pasar atau paling tidak mampu mempengaruhi mekanisme pasar sangat dominan sehingga memaksa pembentuk hukum untuk membuat hukum yang mengaspirasikan kepentingan mereka.

Teori Max Weber mengenai faktor kekuatan ekonomi dalam pembentukan hukum dapat dipersandingkan dengan pendapat para ahli lainnya. Berkaitan dengan teori tersebut Roscoe Pound 24 berpendapat bahwa hukum mengatur kepentingan-kepentingan tertentu yang oleh masyarakat dianggap perlu untuk dilindungi dengan hukum. Setiap peraturan hukum jika dianalisis berdasarkan kepentingankepentingan akan mudah dimengerti oleh masyarakat pada umumnya. Menurut Pound tidak semua kepentingan harus diatur hukum, karena ada kepentingan-kepentingan yang diatur oleh agama, estestika, dan lain-lain. Untuk menentukan ruang lingkup pengaturan diperlukan syarat-syarat sebagai berikut:
1. Inventarisasi terhadap kepentingan-kepentingan yang ada dalam masyarakat.

2. Seleksi kepentingan-kepentingan yang dikenal oleh hukum.

3. Batasan ruang lingkup perlindungan yang telah diseleksi.

4. Pertimbangan tentang cara yang dipakai oleh hukum untuk menjamin kepentingan tersebut.

industry yang pada akhirnya akan sangat menentukan perekonomian suatu Negara.

${ }^{24}$ Roscoe Pound adalah ahli botani yang mendalami hukum. Pound cenderung mengadakan klasifikasi materi hukum dan membedakan antara hukum dengan sosiologi hukum.
5. Evolusi prinsip-prinsip evaluasi mengenai kepentingankepentingan. $^{25}$

Dengan demikian dalam pembentukan hukum, setiap kepentingan yang ada dimasyarakat haruslah diinvestarisis untuk selanjutnya dipilah-pilah mana kepentingan yang berkaitan dengan hukum serta ditimbang bobot berat ringannya tingkat kepentingan yang bersangkutan bagi kesejahteraan masyarakat pada umumnya. Pada prakteknya akan ditemukan benturan kepentingan-kepentingan yang saling bertentangan, oleh karenanya kemudian kepentingan-kepentingan yang berbeda bahkan mungkin yang bertentangan tersebut harus diseimbangkan. ${ }^{26}$ Sehingga dapat dihindari kesenjangan yang terlalu jauh antara kepentingan yang dilindungi dengan kepentingan yang terabaikan. Pada akhirnya setiap kepentingan harus dilihat dari kaca mata masyarakat.

Lebih lanjut Pound mengklasifikasikan kepentingan yang harus dilindungi oleh hukum dalam 3 hal, yaitu ${ }^{27}$ :

1. Kepentingan-kepentingan individu, yaitu tuntutan atau kehendak yang terlibat dalam dan terlihat dari sudut pandang kehidupan individu, meliputi:
a. Kepentingan individu
b. Kepentingan keluarga
c. Kepentingan hak milik

2. Kepentingan-kepentingan sosial/masyarakat, yaitu tuntutan

\footnotetext{
${ }^{25}$ Hari C hand, op.cit., h. 196

${ }^{26}$ Teori keseimbangan antara kepentingan dan tujuan dalam pembentukan hukum, pertama kali dikembangkan oleh Ihering seorang juris yang melakukan studi intensif tentang hukum Romawi.

${ }^{27}$ Darji Darmodiharjo dan Sidharta, PokokPokok Filsafat Hukum apa dan Bagaimana Filsafat Hukum Indonesia, hh. 129-130.
} 
atau kehendak yang terlibat dalam dan terlihat dari sudut pandang kehidupan politik, meliputi:

a. Kepentingan akan kedamaian dan ketertiban

b. Perlindungan lembagalembaga sosial

c. Pencegahan kemorosotan akhlak

d. Pencegahan pelanggaran hak

e. Kesejahteraan sosial

3. Kepentingan-kepentingan

Negara/hukum sebagai pelindung kepentingan sosial yaitu tuntutan atau kehendak yang terlibat dalam dan terlihat dari sudut pandang kehidupan sosial masyarakat beradab, meliputi:

a. Kepentingan Negara sebagai badan hukum

b. Kepentingan Negara sebagai penjaga kepentingan masyarakat

Dalam praktek pembentukan hukum, kepentingan-kepentingan tersebut pertimbangan bagi politik hukum yang melatar belakangi produk hukum yang dihasilkan oleh lembaga legislative. ${ }^{28}$ Teori kepentingan dari Pound merupakan inti ilmu hukum sosiologis, karena kepentingan merupakan suatu keinginan atau permintaan yang ingin dipenuhi manusia baik secara pribadi, hubungan antar pribadi, dan kelompok. $^{29}$

Dari pendapat Roscoe Pound tersebut dapat disimpulkan bahwa meskipun pembentukan hukum tidak lepas dari pengaruh berbagai

${ }^{28}$ Alexander Seran, Moral Politik Hukum, (Jakarta: Obor, 1990), hh. 64-65.

${ }^{29}$ Soerjono Soekanto, Prespektis Teoritis Studi Hukum Dalam Masyarakat, (Jakarta: Erlangga, hh. 30-31). kepentingan, pembentuk hukum (undang-undang) wajib memperhatikan kepentingan mana yang sebenarnya perlu dilindungi dan sedapat mungkin konflik-konflik yang disebabkan oleh perbedaan kepentingan diseimbangkan dengan melihatnya dari sudut pandang kepentingan masyarakat dalam arti luas. ${ }^{30}$

Berkaitan dengan pendapat Weber tentang kepentingan ekonomi sebagai faktor yang utama dalam pembentukan hukum, maka berdasar teori Pound hal tersebut tetap sah dan tidak menjadi masalah sepanjang kepentingan masyarakat luas tetap diperhatikan. Atau dengan kata lain pemberlakuan suatu hukum dimana pembentukannya didasarkan pada kepentingan ekonomi tidak boleh mengabaikan kepentingan masyarakat yang lebih luas atau semata-mata melindungi golongan tertentu yang mempunyai kepentingan.

Barry M. Mitnick ${ }^{31}$ dalam bukunya "The Political Economy Of Regulation" mengemukakan empat teori kepentingan dalam regulasi hukum di bidang ekonomi, yaitu:

1. Customer Protection Theory (kepentingan konsumen);

Suatu peraturan dibuat dengan tujuan untuk melindungi

\footnotetext{
${ }^{30}$ Jika kepentingan yang dilindungi hanya diperuntukan sekelompok kecil masyarakat, maka dalam pembentukan hukumnya materi atau substansi yang dimuat harus pula mempertimbangkan kepentingan kelompok masyarakat lainnya yang lebih besar, sehingga dalam implementasinya kelompok masyarakat yang lebih tidak terlalu dikesampingkan atau dirugikan.

${ }^{31}$ Barry M. Mitnick, The Political Economy of Regulation, (New York: Columbia University Press, 1980), hh. 58-161.
} 
konsumen dari suatu produk atau kegiatan konsumen.

2. Industry Protection Theory (kepentingan industry/pelaku usaha)

Suatu peraturan dibentuk dengan tujuan untuk melindungi kepentingan produsen dari suatu produk atau kegiatan. Dalam hal ini industry dan perwakilan atau asosiasinya merupakan pihak yang berusaha membentuk peraturan perundang-undangan.

3. Bureaucratic Behavior Theory (kepentingan birokrasi/pemerintah)

Teori ini dikelompokkan menjadi dua, yaitu:

a. Maintenance theory, yang mempertahankan status quo pelayanan birokrasi;

b. Expansion theory, yang merupakan bentuk pelayanan yang terbaik dari birokrasi yaitu dengan memperluas wewenang dan mandat dalam pelayanan.

4. Public Interest Theory (kepentingan public)

5. Suatu peraturan perundangundangan dibuat untuk memperhatikan atau menjaga keseimbangan dan kepentingan masyarakat secara keseluruhan.

Termasuk dalam tujuan pembentukan peraturan adalah tujuan nasional untuk pembangunan wilayah atau bidang tertentu untuk kepentingan masyarakat tertentu. Dalam setiap bentuk kepentingan tersebut, Barry $\mathrm{M}$. Mitnick memberikan parameter tertentu untuk menguji apakah substansi suatu undang-undang berorientasi pada salah satu kepentingan atau tidak. ${ }^{32}$ Dengan menggunakan parameter pengujian, dapat dilihat kepentingan ekonomi apa yang menjadi latar belakang (politik hukum) ${ }^{33}$ dibentuknya suatu undang-undang. Selanjutnya dengan melakukan penyelarasan atas teori dari Barry M. Mitnick dan Roscoe Pound, kepentingan ekonomi yang mempengaruhi pembentukan hukum dapat dipertimbangkan bobot kepentingannya bagi masyarakat secara luas.

Dari teori yang di kemukakan Barry M. Mitnick dapat dilihat bahwa setiap kepentingan ekonomi yang mendasari pembentukan hukum haruslah mempunyai kriteria yang jelas dan Barry M. Mitnick memberikan alat penguji pada masing-masing kepentingan untuk mengetahui kepentingan ekonomi yang manakah yang menjadi latar belakang pembentukan suatu undang-undang.

Keterkaitan antara kepentingan dengan pembentukan hukum, pada intinya tidak dapat dilepaskan dari konflik atau perbedaan kepentingan yang timbul dalam masyarakat. ${ }^{34}$ Dalam hal ini Satjipto Raharjo dalam bukunya "Hukum dan Masyarakat" mengutip pendapat Chambliss dan Seidman bahwa di dalam masyarakat dikenal dua model, yaitu pertama model masyarakat yang mendasarkan pada basis kesepakatan nilai-nilai yang

\footnotetext{
${ }^{32}$ Jika terjadi keseimbangan distribusi pada keempat kepentingan, maka dapat tercapai keadilan dari perspektif ekonomi.

33 Politik hukum yang dimaksud adalah dalam arti luas, yaitu dalam rangka menciptakan system hukum yang menjamin kedaulatan rakyat dan keadilan sosial.

${ }^{34}$ Perlu diperhatikan bahwa salah satu tujuan pembentukan hukum adalah untuk mengatasi konflik yang terjadi di masyarakat dalam rangka mencapai ketertiban.
} 
terdapat dalam masyarakat dan yang kedua masyarakat dengan model konflik. $^{35}$

Pada tipe masyarakat dengan model pertama, Landasan kehidupan masyarakat senantiasa didasari oleh kesepakatan-kesepakatan diantara mereka dan mereka cenderung tidak mengenal konflik. ${ }^{36}$ Oleh karenanya masalah yang dihadapi oleh pembuat hukum hanyalah menentukan nilainilai tertentu yang akan diberlakukan kepada masyarakat. Dalam hal ini pembentukan hukum merupakan cerminan nilai-nilai yang disepakati oleh warga masyarakat.

$$
\text { Sedangkan pada tipe }
$$

masyarakat yang kedua, yang menjadi cirinya adalah sering terjadi perubahan dan konflik-konflik sosial. ${ }^{37}$ Pada model masyarakat konfik ini masyarakat dipandang sebagai suatu hubungan dimana masyarakatnya mengalami tekanantekanan yang dilakukan oleh warga masyarakat lainnya. Nilai-nilai yang berlaku dalam masyarakat berada dalam situasi konflik satu sama lain, dimana keadaan ini akan tercermin dalam pembuatan hukumnya.

Pembentukan hukum atau undang-undang seringkali digunakan

\footnotetext{
${ }^{35}$ Satjipo Raharjo, Hukum dan Masyarakat, Hukum dan Masyarakat, cet.1, (Bandung: Angkasa, 1980), h. 49.

36 Pada masyarakat yang mendasarkan kehidupannya pada nilai-nilai kesepakatan jarang sekali ditemukannya ada konflik antar individu di dalamnya, hal ini disebabkan oleh ciri-ciri tertentu yang dimiliki oleh masyarakat yang bersangkutan, antara lain homoginitas masyarakat, masyarakatnya masih sederhana, jumlah individu dari masyarakat yang bersangkutan relatif kecil.

37 Model masyarakat konflik mempunyai cirri tingkat perkembangan masyarakatnya lebih maju dan telah mempunyai pembagian kerja lebih terarah, serta bersifat heterogen.
}

sebagai sarana control atas ekonomi nasional dengan tujuan mencegah atau memupukperkembangan kelas sosial tertentu atau untuk mengarahkan pengaruh asing. Dalam setiap kasus muncul ketegangan antara individu dan kelompok tertentu yang berdampak nyata pada bentuk dan penggunaan hukum yang diciptakan. ${ }^{38}$

\section{Beberapa kasus proses pembentukan hukum di Indonesia}

System hukum di Indonesia mengenal hukum tertulis dan hukum yang tidak tertulis. Hukum tertulis adalah hukum yang ditetapkan oleh lembaga yang berwenang yang sah dan di buat melalui prosedur yang sah. Sedangkan hukum tidak tertulis yang dimaksud disini adalah hukum adat ${ }^{39}$ yang terdapat di berbagai daerah di Indonesia.

Khusus untuk hukum yang tertulis seperti undang-undang, agar hukum yang dibuat sesuai dengan aspirasi masyarakat dan sesuai dengan tujuan yang diharapkan, proses pembentukannya sudah seharusnya selalu melibatkan peran serta masyarakat mulai dari usulan rancangan undang-undang sampai dengan proses pembahasan di legislatif melalui forum Rapat Dengar Pendapat Umum (RDPU)

38 A.A.G. Peters dan Koesriani Siswosoebroto, Hukum dan Perkembangan Jakarta pustaka sinar harapan,1990), h.213

39 Pada masyarakat adat hukum terbentuk dari kebiasaan yang dilakukan oleh individu dan dilakukan secara berulang-ulang sehingga menjadi kebiasaan pribadi yang pada akhirnya diikuti warga masyarakat yang lain sehingga menjadi kebiasaan kolektif. Kebiasaan kolektif ini melembaga menjadi adat yang kemudian diberikan sanksi bagi warga yang melanggarnya. 
maupun pengaduan masyarakat baik secara langsung (lisan) ataupun melalui surat. ${ }^{40}$ RDPU $^{41}$ merupakan rapat antara Subkomisi, Komisi, beberapa Komisi dalam Rapat Gabungan Komisi, Badan Legislasi, atau Panitia Khusus dengan perseorangan, kelompok, organisasi atau badan swasta, baik atas undangan Pimpinan DPR maupun atas permintaan yang bersangkutan yang di pimpin oleh pimpinan Komisi, pimpinan Rapat Gabungan Komisi, Pimpinan Badan Legislasi, atau pimpinan Panitia Khusus. Sedangkan pengaduan masyarakat merupakan sarana yang dimiliki DPR untuk menampung dan menindaklanjuti aspirasi dan pengaduan masyarakat tentang suatu permasalahan yang berada dalam ruang lingkup tugas dan wewenang $\mathrm{DPR}^{42}$ (termasuk untuk menampung aspirasi masyarakat dalam pembentukan undang-undang).

$$
\text { Seperti }
$$

diketahui perkembangan masyarakat Indonesia sejak abad ke-20 telah mengarah pada pola masyarakat yang terbuka, heterogen dan individualitas. Hal tersebut sangat mempengaruhi proses pembentukan hukum, dimana pengelolaan dan distribusi kepentingan dan nilai-nilai yang saling bertentangan dan berbedabeda selalu menjadi poin penting bagi pembuat hukum atau undangundang. Kebijakan kenegaraan yang selama ini ditonjolkan adalah penyeimbangan antara kepentingan individu dengan kepentingan

\footnotetext{
${ }^{40}$ Pasal 141 ayat (2)Peraturan Tata Tertib DPR RI tahun 2001.

${ }^{41}$ pasal 90 Peraturan Tata Tertib DPR RI tahun 2001.

42 pasal 141 ayat 1 peraturanb tata tertib DPR RI tahun 2001.
}

bersama. ${ }^{43}$ Untuk itu permasalahan perbedaan nilai dan kepentingan diselesaikan melalui konsep musyawarah untuk mufakat. Konsep ini dapat diterima ditaati khusunya dalam era pasca kemerdekaan sampai dengan Orde Baru. Namun seiring dengan perkembangan masyarakat yang makin terbuka dan kritis, pada era reformasi konsep tersebut mulai terkikis. Artinya meskipun asas musyawarah dalam pengambilan keputusan tetap dijunjung tinggi, tetapi kemufakatan secara bulat tidak lagi menjadi persyaratan dalam pengambilan keputusan termasuk dalam pembentukan hukum di badan legislatif.

Berikut ini beberapa kasus pembentukan peraturan perundangundangan di Indonesia yang keberadaannya didasari oleh adanya kepentingan-kepentingan khususnya kepentingan ekonomi, namun dalam penataan implementasinya mempunyai dampak yang berbedabeda bagi masyarakat.

\section{Undang-undang No. 40 Tahun 2007 tentang Perseroan Terbatas}

Dominannya faktor kepentingan ekonomi dalam pembentukan hukum dapat dilihat pada kasus yang terjadi di Indonesia. Salah satunya adalah pembentukan undang-undang No.40 Tahun 2007 tentang Perseroan Terbatas. Latar belakang pembentukan undangundang tersebut adalah tekanan dari IMF. Persyaratan dari IMF tersebut

\footnotetext{
${ }^{43}$ Satjipto Raharjo ,op.cit., h.51

${ }^{44}$ Konsep ini merupakan nilai luhur yang dimiliki bangsa indonesia yang berakar dan tumbuh dalam masyarakat sejak zaman dahulu Tujuannya adalah untuk meminimalisir pengaruh perbedaan dan nilai yang saling bertentangan .
} 
diluluskan karena pemerintah Indonesia tidak mau kehilangan pinjaman dari IMF untuk menangani krisis ekonomi yang tengah berlangsung. 45 Bahkan proses pembentukannya tergolong cepat meskipun tidak termasuk dalam prioritas undang-undang yang akan di bahas oleh Dewan Perwakilan Rakyat dan Pemerintah pada tahun 2007. ${ }^{46}$ Lemahnya posisi tawar pemerintah memaksanya untuk membentuk undang-undang tersebut, sementara fakta di lapangan pengaturan substansi tersebut jauh dari realitas masyarakat selaku obyek hukum. Jika melihat realitas kehidupan masyarakat Indonesia yang sebagian besar berada di garis kemiskinan dan berpendapatan minim dan hanya sebagian sebagian kecil saja yang mampu menduduki peringkat atas dari sisi pendapatan maka keberadaan undang-undang tersebut relatif tanpa makna. Masyarakat khsusnyayang berada di pedesaan tidak mengetahui apa itu pencucian uang. Disamping itu dibutuhkan penelitian yang akurat apakah kegiatan pencucian uang memang ada atau potensial untuk dilakukan di Indonesia ? lalu dimana fungsi hukum yang akan ditegakkan jika memang praktek pencucian uang tidak dikenal di Indonesia ?. Dengan kata lain landasan atau pertimbangan

\footnotetext{
${ }^{45}$ Letter of intens yang ditanda tangani bersama antara Pemerintah Indonesia dengan IMF menyaratkan beberapa pembentukan undang-undang oleh DPR, salah satunya UU tentang Tindak Pidana Pencucian Uang.

46 Undang-undang tentang Prioritas merupakan landasan hukum bagi DPR dan Pemerintah dalam menyusun serta membentuk undang-undang dalam suatu periode keanggotaan DPR dan Setiap Tahun anggaran.
}

filosofis, yuridis, dan sosiologis yang seharusnya menjadi landasan pembentukan undang-undang ${ }^{47}$ sama sekali terabaikan. Sehingga dapat dikatakan tingkat urgenitas dan kegunaan undang-undang perseroan terbatas relative sangat rendah. Relevan dengan pendapat tersebut menurut Bagir Manan, unsur-unsur filosofis, ${ }^{48}$ yuridis ${ }^{49}$ dan sosiologis ${ }^{50}$ merupakan dasar bagi berlakunya hukum yang baik. Karenanya setiap pembuat undang-undang berharap agar kaidah yang tercantum dalam perundang-undangan adalah sah secara hukum (legal validity) dan berlaku efektif atau dapat diterima oleh masyarakat secara wajar dan berlaku untuk jangka waktu yang panjang. ${ }^{5}$

Hal tersebut mencerminkan keberadaan Undang-Undang Nomor 15 tahun 2002 tentang Tindak Pidana Pencucian Uang merupakan produk hukum yang mempunyai

\footnotetext{
${ }^{47}$ Amiroedin Sjarif, Perundang-Undangan Dasar, Jenis, dan Teknik Membuatnya,(Jakarta: Rineka Cipta, 1997), h. 91 .

48 Bagir Manan dalam bukunya DasarDasar Perundang-Undangan Indonesia menyatakan bahwa hukum hendaknya mencerminkan cita hukum atau rechtsidee yang menyangkut pandangan atau hakekat sesuatu yang tumbuh dari sistem nilai dalam masyarakat. Hukum diharapkan mencerminkan sistem nilai tersebut baik sebagai sarana yang melindungi nilai-nilai atau sebagai sarana mewujudkannya dalam tingkah laku masyarakat.

${ }^{49}$ Hukum harus dibuat oleh lembaga yang berwenang, adanya kesesuaian antara bentuk atau jenis peraturan perundang-undangan dengan materi yang diatur, terutama kesesuaian dengan peraturan yang lebih tinggi, mengikuti prosedur yang sah.

${ }^{50}$ Artinya hukum hendaknya mencerminkan kenyataan yang hidup dalam masyarakat.

${ }^{51}$ Bagir Manan, Dasar-Dasar PerundangUndangan Indonesia, cet. Pertama, (Jakarta: Ind-Hill.Co, 1992), hh. 13-14.
} 
karakteristik hukum konservatif atau ortodoks. Artinya, produk hukum yang dihasilkan isinya lebih mencerminkan keinginan pemerintah, bersifat positivis-instrumentalis, yaitu menjadi alat bagi pelaksanaan idiologi program Negara. Hukum ini lebih bersifat tertutup terhadap tuntutan masyarakat maupun individu-individu. Disamping itu pembuatan hukum dengan karakter yang konservatif atau ortodoks cenderung memberikan porsi yang lebih kecil terhadap peran serta masyarakat. ${ }^{52}$ Memang tidaklah tepat jika dikatakan bahwa undang-undang Perseroan terbatas tidak akan bermanfaat sama sekali bagi masyarakat, karena pembelaan terhadap hal tersebut memang ada, yaitu bahwa undang-undang no. 40 Tahun 2007 merupakan bentuk antisipasi hukum di masa depan (unsure predictability). ${ }^{53}$

\section{Undang-Undang Nomor 25 Tahun 2007 tentang Pernanaman Modal}

Dalam kasus yang berbeda pembentukan Undang-undang Nomor 25 Tahun 2007 tentang Penanaman modal, melalui analisis deskriptif dapat dilihat adanya kepentingan ekonomi yang dominan. Namun kepentingan tersebut tidak hanya milik golongan tertentu yaitu pelaku usaha, tetapi juga kepentingan

52 Moh. Mahmud MD, Perkembangan Politik Hukum Studi Tentang Pengaruh Konfigurasi politik Terhadap Produk Hukum di Indonesia, Disertasi Doktor dalam Ilmu Hukum, Unniversitas Gajah Mada, Yogyakarta, 1993.

53 Max Weber menyebut pembentukan hukum yang bertujuan sebagai langkah proteksi atau antisipasi terhadap masyarakat di masa yang akan datang sebagai unsur perdictability yang semestinya diperhatikan dalam pembentukan hukum. masyarakat luas selaku konsumen bahkan termasuk di dalamnya kepentingan birokrasi atau pemerintah dan kepentingan public atau nasional. Pada kasus ini terlihat bahwa hukum dapat mempengaruhi aktifitas ekonomi, dalam hal ini pelaku usaha di paksa untuk melakukan prosedur tertentu yang meluindungi konsumen dari kerugian. Menurut pendapat Inosentius Samsul ${ }^{54}$ terkait dengan undangundang penanaman modal, pembentuk undang-undang dalam hal ini Dewan Perwakilan Rakyat dan Pemerintah dalam rangka menciptakan distribusi keadilan sudah secara cermat membagi peran dan kesempatan serta perlindungan kepentingan dari empat komponen berdasarkan prespektif politik ekonomi hukum yaitu kepentingan konsumen, pelaku usaha, pemerintah/birokrasi dan kepentingan nasional.

Bahkan secara normative rumusan dalam undang-undang penanaman modal memberikan porsi dan orientasi yang kuat terhadap para pemilik modal dan pemerintah. Dengan demikian undang-undang penanaman modal mempunyai sifat yang demokratis dan populis ${ }^{55}$ yang

\footnotetext{
54 Inosentius Samsul, “Undang-Undang Perlindungan Konsumen dari Prespektif Politik Ekonomi Hukum (Politycal economy Of Law)" dalam Reformasi Hukum Nasional Suatu Kajian Terhadap Undang-Undang Produk Pemerintah Transisi 1998-1999, h. 218.

${ }^{55}$ Mahmud MD menyebut produk hukum yang populistik sebagai produk hukum yang mencerminkan rasa keadilan dan memenuhi harapan masyarakat dimana dalam di dalam pembentukannya memberikan kesempatan yang cukup besar kepada kelompok sosial maupun individual dalam masyarakat dan bersifat responsif terhadap tuntutan
} 
mengakomodasi kepentingan masyarakat, dalam hal ini kepentingan para investasi.

Meski pada satu sisi undangundang penanaman modal mempunyai karakter yang populis, namun pada sisi yang lain peran dari pemerintah masih sangat menonjol. Hal tersebut menunjukkan tekad pemerintah untuk tetap berpengaruh terhadap perlindungan para investor. Meskipun dari materi pengaturan undang-undang penanaman modal terlihat kepentingan para investor dan pemerintah/birokrasi jauh lebih menonjol jika dibandingkan dengan kepentingan pelaku usaha dan kepentingan nasional/public, namun untuk jangka panjang atau hasil implementasi dari undang-undang penanaman modal diharapkan akan memberikan andil atau peran yang signifikan dalam rangka mewujudkan kesejahteraan umum/masyarakat serta melahirkan pelaku usaha serta produk barang dan jasa nasional yang memiliki standar kualitas tinggi sehingga mampu bersaing dalam pasar global. $^{56}$

\section{Perpu Nomor 1 tahun 2002 tentang Terorisme}

Latar belakang dibentuknya Perpu nomor 1 tahun 2002 tentang terorisme akibat tekanan dari dunia internasional khususnya Amerika Serikat. Tuduhan beberapa Negara barat bahwa Indonesia merupakan salah satu tempat jaringan terorisme

kelompok-kelompok yang ada dalam masyarakat.

${ }^{56}$ Sebagai anggota ASEAN, maka Indonesia terikat pada kesepakatan AFTA yang menerapkan pasar bebas dikawasan ASEAN mulai tahun 2003. internasional telah mendorong Negara-negara Eropa dan Amerika untuk menekan Indonesia agar segera membuat Undang-undang tentang Anti terorisme.

Tekanan tersebut makin kuat manakala terjadi peristiwa pemboman di Kuta Bali ${ }^{57}$ yang menewaskan turis-turis dari berbagai Negara.Meskipun belum terbukti secara hukum Indonesia terkait dalam jaringan teroris internasional tetapi pemerintah republik Indonesia tidak berdaya dengan tekanan dari Negara-negara lain berikut ancamannya,sehingga pemerintah mengeluarkan Peraturan Pemerintah Penganti Undang-undang Nomor 1 tahun 2002 Tentang Terorisme. Peraturan Pemerintah Penganti Undang-undang merupakan salah satu peraturan perundangan yang dikenal dalam Tata Urutan Peraturan Perundangan Indonesia. ${ }^{58}$ Undangundang Dasar 1945 menyebutkan bahwa dalam hal ikhwal kegentingan yang memaksa,Presiden berhak menetapkan peraturan pemerintah sebagai penganti undang-undang. ${ }^{59}$

Dipilihnya bentuk Perpu dimahsudkan untuk dapat segera memberlakukanperaturan tentang terorisme, ${ }^{60}$ sebab jika harus dikeluarkan dalam bentuk undangundang akan memerlukan waktu

\footnotetext{
57 Peristiwa tersebut menjadi alasan yang kuat bagi Amerika dan negara-negara barat untuk menekan Indonesia agar sesegera mungkin membuat hukum yang dapat menjerat pelaku-pelaku terorisme.

58 TAP MPR NO. III/MPR/2000 Tentang Sumber Hukum Dan Tata Urutan Peraturan Perundang-Undangan

${ }^{59}$ Pasal 22 ayat (1) UUD 1945.

${ }^{60}$ Pada banyak negara belum ada kesatuan tentang pengertian dan ruang lingkup dari terorisme. Hal ini akan berdampak pada pemberlakuan interpretasi yang berbedabeda.
} 
yang lebih lama dalam prosedur pembahasannya di Dewan Perwakilan Rakyat, sementara tuntutan untuk segera mengeluarkan landasan hukum bagi kejahatan teroris terus berlangsung,contohnya pelaku terror bom telah ditangkap oleh penegak hukum masi saja terror bom masi berlangsung dibumi Indonesia.

Menurut Soehino, Perpu ditetapkan untuk mengatur suatu materi yang sebenarnya merupakan materi dari undang-undang,tetapi karena suatu keadaan dan kondisi yang mendesak yang tidak mungkin ditangguhkan sampai adanya sidang Dewan Perwakilan Rakyat yang akan membahas undang-undang dengan materi tersebut maka untuk mengatasinya dan agar keamanan Negara dapat dijamin oleh pemerintah,oleh sebab itu pemerintah bertindak cepat dan tepat dengan membuat peraturan perundang-undangan yang mempunyai nilai sederajat dengan undang-undang. ${ }^{61}$ Karena alasanalasan tersebut maka proses perundang-undangan untuk Perpu lebih singkat dan beberapa tahap dipersingkat seperti Panitia antar Departemen tidak selalu diperlukan dan pertimbangan atau tanggapan menteri/Kepala Lembaga Pemerintah Non Departemen yang bersangkutan dilakukan secara singkat. ${ }^{62}$

Mengingat sifat keberlakuan Perpu yang harus segera mendapat persetujuan dari Dewan Perwakilan Rakyat dalam persidangan yang

61 Soehino, Ilmu Negara,(Yogyakarta: Liberty, 1980), h. 34.

${ }^{62}$ A. Hamid S Attamimi, Ilmu PerundangUndangan Dasar-Dasar dan Pembentukannya, cet. 5, (Jakarta: Kanisius, 2001), h. 151. berikutnya ${ }^{63}$ dan jika tidak mendapatkan persetujuan Dewan maka peraturan pemerintah penganti undang-undang tersebut harus dicabut, ${ }^{64}$ oleh karenanya saat ini tengah disiapkan rancangan undangundang tentang Terorisme yang pembahasannya akan segera dilakukan di DPR. ${ }^{65}$ Sejalan dengan keharusan mendapatkan persetujuan DPR pada sidang berikutnya, menurut Jimly Asshiddiqie, tenggang waktu satu tahun yang diberikan kepada pemerintah untuk menjalankan aturan yang telah dibuatnya tanpa persetujuan DPR pada dasarnya cukup longgar,karena dibeberapa Negara modern tenggang waktu berlakunya undang-undang darurat atau emergency law relatif lebih pendek untuk menghindari penyalahgunaan oleh penguasa,sebagai contoh dalam Konsititusi India masa berlakunya emergency law hanya tiga bulan ${ }^{66}$.

Mempelajari kasus- kasus pembentukan hukum yang terjadi di Indonesia membuktikan bahwa dominasi kepentingan ekonomi selalu menjadi latarbelakang pembuatan hukum. Namun pada dasarnya suatu hukum dibuat untuk menciptakan ketertiban dalam masyarakat,sehingga subtansi yang diaturnya haruslah merupakan refleksi dari keadaan masyarakat yang memerlukan ketertiban.Dengan demikian salah satu tujuan hukum adalah untuk mengatasi

${ }^{63}$ Pasal 22 ayat (2) UUD 1945.

${ }^{64}$ Pasal 22 ayat (3) UUD 1945

${ }^{65}$ Pada saat tulisan ini disusun, RUU tentang Terorisme berada pada tingkat I pembahasan di DPR RI.

66 Jimly Asshiddiqie, Konsolidasi Naskah UUD 1945 Setelah Perubahan Keempat, (Jakarta: Pusat Studi Hukum Tata Negara Fakultas Hukum Universitas Indonesia, 2002), h. 29. 
permasalahan atau konflik-konflik yang terjadi dimasyarakat,sehingga pada akhirnya dapat tercapainya ketertiban hukum.Ciri pembentukan yang demikian dikenal dalam masyarakat dengan model konflik,dimana pembentukan hukum salah satu penyebabnya dilatar belakangi oleh keinginan untuk memperkecil kemungkinankemungkinan terjadinya konflik atau perbedaan kepentingan-kepentingan yang ada dalam masyarakat bersangkutan sebagai refleksi dari berbagai macam pola masyarakatnya Selanjutnya hukum sebagai positivasi nilai moral adalah legitim karena adil.Dalam hal ini keadilan menuntut penguasa menempatkan kepentingan umum sebagai tujuan hukum. ${ }^{67}$ Namun tidak dapat dipungkiri bahwa substansi pengaturan hukum sebaiknya juga berorientasi kemasa depan. Kemungkinan-kemungkinan yang akan timbul dari masalah hukum di masa depan harus dapat diprediksi, hal ini dilakukan dalam rangka mencegah terjadinya kekosongan hukum dan adanya jaminan kepastian hukum bagi seluruh rakyat Indonesia khususnya para pelaku kegiatan perekonomian.

\section{Prespektif Pembentukan Hukum di Era yang Akan Datang}

Hukum sebagai alat perubahan sosial sekaligus sarana pengatur ketertiban masyarakat haruslah mencerminkan keadaan masyarakat yang diaturnya. Disamping itu hukum yang berlaku juga harus mampu menyelesaikan konflik-konflik yang ada dimasyarakat.Berkaitan dengan makin modernya sistem ekonomi dan

${ }^{67}$ Alexander Seran, op. cit, h. 52. teknologi yang membutuhkan pengaturan hukum dalam setiap transaksi yang diadakannya,maka pembentukan hukum tidak lepas dari pengaruh kepentingan ekonomi sebagaimana yang telah dikemukankan oleh Max Weber.

Namun demikian pembentuk undang-undang hendaklah mempertimbangkan secara masak apakah kepentingan ekonomi yang akan menjadi dasar pembentukan suatu undang-undang tidak mengabaikan keadilan masyarakat dalam arti yang luas.Hal ini sesuai dengan pendapat aliran hukum kritis yang memandang hukum sebagai bagian dari masyarakat dan hukum disatu pihak merupakan unsur dari perbandingan kekuatan yang nyata dan kepentingan-kepentingan yang dominan sedang dilain pihak hukum merupakan aspirasi keadilan dan legistimistis. ${ }^{68}$

Prinsip keseimbangan dan keadilan dalam pembentukan hukum seyogyanya menjadi pedoman bagi pembentuk undang-undang.Menurut Richard A.Posner, ada dua prinsip keadilan yaitu pertama prinsip yang menekankan pada kesederajatan hak individu dan kemerdekaan individu.Sedangkan yang prinsip yang kedua menekankan pada kesejahteraan individu secara sosial ekonomi. Kedua prinsip tersebut harus diatur dalam peraturan perundang-undangan. ${ }^{69}$ Relevan dengan pendapat tersebut proses pengaturan hukum haruslah memperhatikan hak-hak individu

\footnotetext{
${ }^{68}$ Sudjono Dirjosisworo, Sosiologi Hukum Studi Tentang Perubahan Hukum dan Sosial, (Jakarta: Rajawali Press), h. 9.

69 Richard A. Posner, The Problem of Jurisprudence, (Cambirige-MassachusettsLondon: Harvard Univercity Press, 1995), hh. 334-348.
} 
khususnya hak-hak dasar dan berorientasi pada kesejahteraan ekonomi masyarakat kecil. Pembentukan hukum yang bersumber pada nilai-nilai yang ada dimasyarakat relatif akan lebih efektif dari sisi penerapannya. ${ }^{70}$

Disamping hal tersebut,penentuan kepentingan yang akan menjadi latar belakang pembuat undang-undang hendaklah melalui pertimbangan yang akurat dalam arti perlu dipikirkan kemungkinan dan dampak implementasi dari undang-undang atau hukum yang bersangkutan,apakah berorientasi kepada kesejahteraan masyarakat dalam arti yang luas.Sehingga meskipun pada awalnya hukum yang dibuat dilatar belakangi kepentingan ekonomi yang mewakili kelompok tertentu saja, namun dalam penerapan jangka panjang masyarakat umum diluar kelompok yang berkepentingan ikut merasakan manfaatnya. ${ }^{71}$

Hal lain yang perlu diperhatikan,dalam

perkembangannya dewasa ini dimana era perdagangan bebas mulai dibuka,dominasi kepentingan ekonomi dalam aktifitasnya untuk mempengaruhi pembentukan hukum semakin kuat. Era globalisasi yang ditandai dengan terbentuknya berbagai organisasi negara-negara yang menyepakati berlakunya pasar bebas seperti World Trade

\footnotetext{
${ }^{70}$ Relevan dengan pendapat Kelsen bahwa aspek ganda dari hukum yang diundangkan adalah hukum diperuntukan bagi warga negara agar bertindak sesuai hukum yang ditetapkan dan hukum ditujukan pada hakim agar menerapkan sanksi jika ada warga negara yang melanggarnya.

${ }^{71}$ Dalam pembentukan hukum selain normanorma yuridis, perlu juga diperhatikan segi moral sebagai salah satu upaya menjamin kepentingan umum dalam arti luas.
}

Organization(WTO), ${ }^{72}$ Asean Free Trade Area (AFTA), ${ }^{73}$ North American Free Trade Agreement (NAFTA), 74 dan lain sebagainya,mengharuskan setiap negara untuk memberikan jaminan hukum dan keamanan bagi investasi yang masuk tanpa membedakan investor dalam negeri maupun investor asing.Jika hukum dari negara yang bersangkutan tidak mampu memberikan jaminan perlindungan hukum dan kepastian hukum serta keamanan bagi investasi mereka,maka para investor asing enggan menanamkan modal dan melakukan usahanya dinegara tersebut.Bahkan kemungkinan yang lebih buruk,investor dalam negeripun akan melarikan modalnya kenegara lain,karena merasa usahanya lebih aman dan menguntungkan di Negara lain. $^{75}$

Jaminan perlindungan dan kepastian hukum ini tidak hanya diperlukan pada peraturan yang mengatur masalah-masalah yang terkait langsung dengan bidang perekonomian atau investasi saja,tetapi lebih dari itu berbagai peraturan perundangan yang secara tidak langsung dapat mempengaruhi keberadaan atau keberlangsungan

72 WTO merupakan hasil perundingan Uruguay Round 1986-1984 yang pada intinya merupakan penerus dan pengganti dari GATT yang telah berdiri sejak 1947.

73 AFTA merupakan pemberlakuan pasar bebas di kawasan ASEAN yang beranggotakan 10 negara Asia Tenggara, AFTA akan diterapkan mulai tahun 2003.

74 NAFTA merupakan kesepakatan pemberlakuan pasar bebas di kawasan Amerika Utara yang mulai ditetapkan sejak 1 Januari 2002.

${ }^{75}$ Krisis ekonomi yang berlangsung sejak 1998 diikuti dengan situasi keamanan yang kurang stabil di beberapa daerah di Indonesia berdampak pada rendahnya minat investor untuk berbisnis di Indonesia. 
penyenggalaraan perekonomian juga dituntut berpihak pada kepentingan ekonomi secara makro.

Dalam prakteknya,disatu sisi perlindungan terhadap kepentingan ekonomi melalui jaminan perundangundangan mutlak diperlukan karena Negara sendiri mempunyai andil kepentingan didalamnya khususnya dalam rangka menciptakan stabilitas perekonomian dalam negeri maupun dalam rangka menjalin hubungan perekonomian yang harmonis dengan Negara lain. Jika perekonomian terjamin dan sisi hukum maka Negara akan memetik hasilnya yang berhasil pada peningkatan kesejahteraan rakyatnya. ${ }^{76}$ Pada sisi lain tidak semua pembentukan hukum ekonomi yang dilandasi kepentingan ekonomi dapat bermanfaat bagi masyarakat luas.Hal tersebut dapat dilihat contoh proses pembuatan undang-undang penanaman modal yang hanya melindungi para pelaku ekonomi saja atau golongan tertentu.Disamping produk hukum yang mengcopy undang-undang Negara lain tidak dapat digunakan untuk memecahkan masalah yang sama pada Negara yang berbeda, karena suatu undangundang yang baik dan sesuai untuk suatu Negara tertentu belum tentu tepat dan bermanfaat bagi Negara lain. $^{77}$

\footnotetext{
${ }^{76}$ Dewasa ini ketergantungan antar negara semakin kuat, khusunya negara berkembang terhadap negara maju, negara yang perekonomiannya kuat cenderung menekan negara lain melalui penetapan aturan sebagaimana yang mereka kehendaki.

77 Ann Seidman dan Robert B. Seidman, Perancang Undang-Undang Untuk perubahan Sosial yang Demokratis: Buku Panduan Untuk Anggota Parlemen, Konsep Pertama, (Jakarta: Ellips Project, 2002).
}

Untuk itu penyelarasan konflik kepentingan yang timbul dari kelompok-kelompok yang ada dimasyarakat memegang peranan yang signifikan dalam pembentukan undang-undang agar bisa dicapai tujuan hukum yaitu menciptakan ketertiban.Menurut pendapat Roscoe Pound bahwa hukum mencerminkan kebutuhan-kebutuhan masyarakat teratur. ${ }^{78}$ Hukum mengatur hubungan manusia dengan mengendalikan tindakan individu serta dengan menyelesaikan konflikkonflik diantara kelompok-kelompok yang mengadakan persaingan.

Salanjutnya Roscoe Pound menyatakan bahwa dipandang dari segi fungsinya,maka hukum merupakan suatu usaha untuk memenuhi,mendamaikan,menyerasik an dan menyesuaikan tuntutan dan permintaan (kepentingan )yang beraneka ragam dan tidak jarang bertentangan satu sama lain. Hal tersebut dapat dilakukan melalui penetapan hukum secara langsung dan secepatnya(tanpa kompromi),atau dengan memberikan perlindungan kepada kepentingan individu-individu,atau melalui cara pembatasan atau kompromi kepentingan-kepentingan individu sehingga dapat memberikan pengaruh kepada kepentingan yang lebih besar secara keseluruhan. Melalui pengorbanan yang relatif kecil diharapkan mampu mencapai kepentingan yang lebih besar secara keseluruhan.

Penyelarasan berbagai kepentingan yang saling bertentangan ditujukan agar konflik yang terjadi dimasyarakat dapat diminimalisir dan masyarakat secara keseluruhan dapatmengambil manfaat dari

\footnotetext{
${ }^{78}$ Mulyana W. Kusumah dan Paul S. Baut. ed, op. cit, hh. 95-98.
} 
dibentuknya suatu aturan hukum. Dengan kata lain pembentukan hukum dapat dilakukan dengan mengabaikan kepentingankepentingan tertentu yang relatif lebih kecil, untuk melindungi kepentingan masyarakat yang lebih luas. Hal tersebut relevan dengan pendapat Parson bahwa fungsi utama suatu system hukum bersifat integratif,artinya untuk mengurangi unsure-unsur konflik yang potensial pada masyarakat dan untuk melancarkan proses pergaulan sosial. $^{79}$

\section{Penutup}

1. Sesungguhnya pembentukan hukum yang dicita-citakan oleh UUD 1945 adalah pembangunan ekonomi dan pembangunan hukum yang mencakup juga pembangunan politik dan budaya yang berasal dari kata "mewujudkan keadilan sosial bagi seluruh rakyat Indonesia " adalah wujud dari keadilan dari berbagai segi.

2. Semakin kompleksnya masalah ekonomi, penggabungan ekonomi Negara-negara serta teknologi dalam proses perdagangan telah banyak membuat undang -undang yang didalam terkandung kepentingan ekonomi sehingga begitu banyaknya undang-undang sebenarnya menimbulkan salah penafsiran oleh masyarakat awam sehingga perlu adanya penegakan hukum yang tegas dari aparat pemerintah.

\footnotetext{
${ }^{79}$ Dalam Bambang Suggono, Hukum dan Kebijaksanaan Publik, (Jakarta: Sinar Grafika, 1994), h. 95.
}

\section{DAFTAR PUSTAKA}

A. Hamid S Attamimi, Ilmu Perundang-Undangan DasarDasar dan Pembentukannya, cet. 5, (Jakarta: Kanisius, 2001),

A.A.G. Peters dan Koesriani Siswosoebroto, Hukum dan Perkembangan Jakarta pustaka sinar harapan,1990)

Amiroedin Sjarif, PerundangUndangan Dasar, Jenis, dan Teknik Membuatnya,(Jakarta: Rineka Cipta, 1997),

Bagir Manan, Dasar-Dasar Perundang-Undangan

Indonesia, cet. Pertama, (Jakarta: Ind-Hill.Co, 1992), .

Barry M. Mitnick, The Political Economy of Regulation, (New York: Columbia University Press, 1980).

Hari chand ,Modern Jurisprudence (Kuala Lumpur , International Law Book Service ,1994,)

Inosentius Samsul, "UndangUndang Perlindungan

Konsumen dari Prespektif Politik Ekonomi Hukum (Politycal economy Of Law)", dalam Reformasi Hukum Nasional Suatu Kajian Terhadap Undang-Undang Produk Pemerintah Transisi 1998-1999, .

Jimly Asshiddiqie, Konsolidasi Naskah UUD 1945 Setelah Perubahan Keempat, (Jakarta: Pusat Studi Hukum Tata Negara Fakultas Hukum Universitas Indonesia, 2002), .

Moh. Mahmud MD, Perkembangan Politik Hukum Studi Tentang Pengaruh Konfigurasi politik Terhadap Produk Hukum di 
Indonesia, Disertasi Doktor dalam Ilmu Hukum, Unniversitas Gajah Mada, Yogyakarta, 1993

Richard A. Posner, The Problem Of Jurisprudence, (CambirigeMassachusetts-London:

Harvard Univercity Press, 1995),

Satjipo Raharjo, Hukum dan Masyarakat, Hukum dan Masyarakat, cet.1, (Bandung: Angkasa, 1980), .

Sudjono Dirjosisworo, Sosiologi Hukum Studi Tentang Perubahan Hukum dan Sosial, (Jakarta: Rajawali Press),

T.Mulya lubis dan Richard M.Buxbaum,ed."Peranan Hukum dalam Perekonomian Di Negara Berkembang" (Jakarta :yayasan LBHI. 